\title{
sciendo MECHANISATION OF LONGWALL EXTRACTION OF HARD AND ABRASIVE ROCKS
}

doi:10.2478/mape-2018-0042

Date of submission of the article to the Editor: 04/2018

Date of acceptance of the article by the Editor: 07/2018

MAPE 2018, volume 1, issue 1, pp. 331-337

PhD., Eng. Łukasz Bołoz

Prof. dr hab. inż. Krzysztof Krauze

AGH University of Science and Technology, Poland

Ing. Tomáš Kubín, PhD.

VSB-Technical University of Ostrava, Czech Republic

\begin{abstract}
The article presents the current topic of the possibility of mechanical extraction of hard and abrasive rocks using mechanized wall systems. The problem of extracting ores from thin strata precludes the possibility of further use of current technologies involving a human at the face. Currently, the operation is carried out using explosives in column-pillar systems. In systems with a chamber column, all major processes are mechanized and carried out by self-propelled drilling and bolting machines, loaders as well as hauling and auxiliary trucks. These machines are operated in the workplace by operators. For many years, effective mechanical excavation methods were sought that would allow the development of a mining machine and a mechanised longwall complex. Such a complex is to allow excavation without the presence of humans at the face. The article presents the current technical capabilities, assumptions and requirements for such a solution. Then, an innovative longwall complex equipped with a disc shearer is introduced. The technology of work and achievable productivity are briefly presented. A worn shearer, a face conveyor and a powered support are the subject of AGH inventions.
\end{abstract}

Keywords: mechanical ore excavation, longwall system, disc cutting head.

\section{INTRODUCTION}

At present, in both domestic and global ore mining, excavation using room and pillar mining systems with the use of explosives are widely used. In the mining process, machines such as drilling and bolting trucks, loaders and transporters play an important role. At the same time, problems with mechanical excavation of ores as well as transport of spoil with commonly used armoured conveyors are generally known. The increasingly thinner and deeply deposited layers make it impossible to continue using these machines and, as a result, methods. Therefore, alternative ways of mechanizing the ore mining process are sought. The most susceptible to mechanization and automation is the longwall system equipped with a mechanized complex. However, due to a number of restrictions, it is not possible to apply or adopt existing ore mining solutions (Krauze and Bołoz, 2018). A longwall complex intended for ore mining must consist of hard and abrasive rocks; a face conveyor transferring highly abrasive muck; powered roof support adapted to work in thin seams, and a control system allowing withdrawal of the crew from the longwall during operation (Bołoz, 2013).

For many years, methods have been sought for the mechanical excavation of compact, exceptionally hard and abrasive rocks (Biały, 2014), (Bialy and Krauze, 2018), (Fries et al., 2016), (Krauze et al. 2015), (Stopka et al., 2013). There are two known solutions of complexes that were tested in thin ore deposits: the MN 220 Continuous reef miner by Sandvik (formerly Alpine Reef Miner ARM1100 Voest Alpine) and Cat ${ }^{\circledR}$ Rock Straight System mechanized 
complex by CAT, however, their use ended with underground trials (Fig. 1). The ARM1100 shearer is equipped with a cutting head armed with disc cutters. The combination of the pivoting motion of the arm with the swinging motion of the cutting head allows the cutting of the face using undercutting technology. The solution is designed for headings with a height of 1.1 $\mathrm{m}$. The shearer spreads out in the heading and excavates a face with a width of approximately $4.3 \mathrm{~m}$.
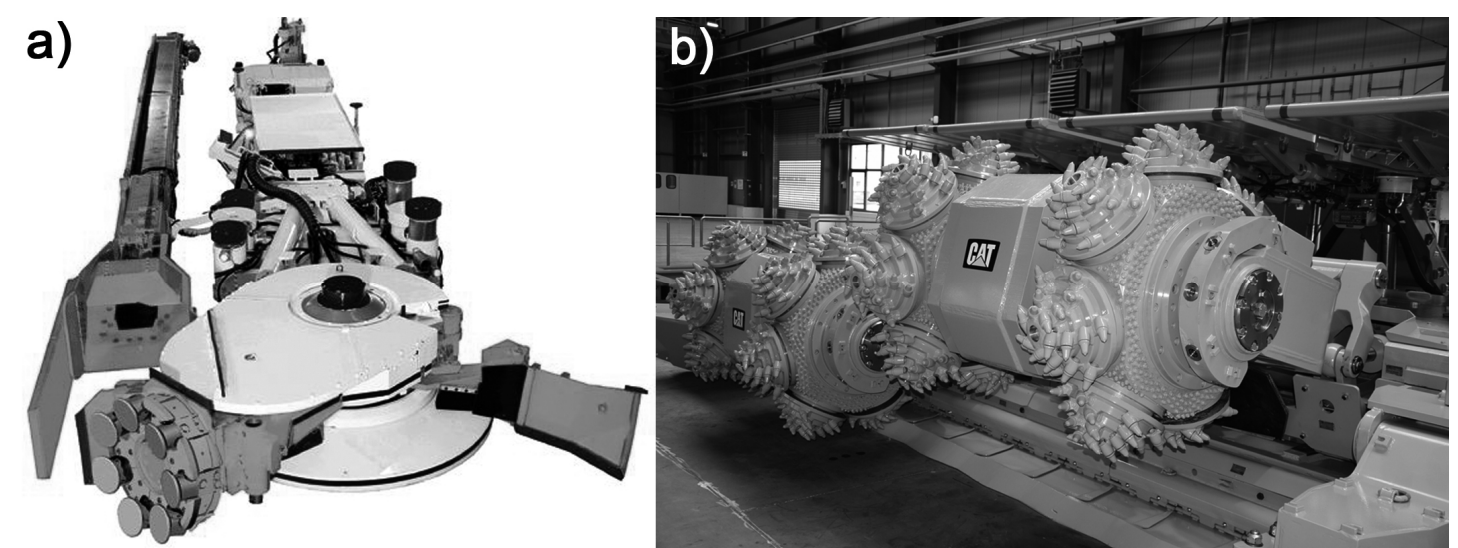

Fig. 1. Ore excavation machines

a) Sandvik MN 220 shearer, b) CAT Hard Rock Miner shearer

The CAT solution utilizes a shearer using the process of rear undercutting with classical conical picks. Apart from shearer, the complex is also equipped with a powered roof support and a plate face conveyor.

The unique complex developed at AGH was designed for the mechanical excavation of copper, iron, zinc and lead ore deposits in the form of more or less regular seams.

The mechanical properties of ores were determined on the basis of tests, in excavations at a depth of $740 \mathrm{~m}$ to $850 \mathrm{~m}$, selected and indicated by the user, as the planned workplaces of the mechanical ore mining complex. At present and in the past, many different systems of mechanisation of excavation of useful minerals have been used. In general, it can be concluded that ores were not mechanically extracted on an industrial scale. Therefore, a solution or the inspiration to develop a solution should be sought in mechanisation systems as well as in scientific research and industrial works carried out as part of the extraction of other minerals (hard and brown coal, rock and potassium salt).

In order to develop the subject system, an analysis of subject literature and the current state of knowledge was conducted. Laboratory and industrial tests were carried out in underground conditions, and broadly defined conceptual and design works as well as simulation studies were conducted.

Development of an ore mining complex due to the necessity to solve a number of problems, also ones regarding durability (Gajewski et al., 2008; Krauze et al., 2015) efficiency and dust levels (Prostański, 2017), will be characterized by innovative solutions (Zasadzień and Midor, 2015).

\section{MECHANICAL ORE EXTRACTION SYSTEM}

The most important element that determines further work of the complex is the cutting head. As part of the implementation of earlier research works, a cutting head equipped with disc cutters was designed, made and tested in laboratory conditions. Positive results of those tests allowed for undertaking activities aimed at creating an ore excavation complex. Based on the analysis of mining and geological conditions and the requirements of the future user, the basic assumptions and requirements regarding the machine complex in question, its functionality and efficiency were specified. The complex is to enable the automatic 
excavation of ore deposits in the height range from $1.0 \mathrm{~m}$ to $2.0 \mathrm{~m}$, with an average output of $50 \mathrm{Mg} / \mathrm{h}$ in rocks with ultimate compressive strength from $15 \mathrm{MPa}$ to $200 \mathrm{MPa}$.

It was proposed to use a complex equipped with an innovative longwall shearer (Bołoz, 2013), a powered roof support (Krauze et al., 2017) and a face belt conveyor. All of the machines mentioned are inventions of $\mathrm{AGH}$.

In the first stage, the geometrical and kinematic parameters of the shearer, conveyor and support were determined, which allowed developing the concept and model of such a solution. Fig. 2 shows a preliminary design of a longwall shearer unit consisting of a longwall shearer 1 , a longwall belt conveyor 2 , a powered roof support section 3 , and a low-face belt conveyor 4 . The ends of the longwall conveyor include its drives 5 and drives of a 6 -chain haulage system of the shearer. The shearer moves on four skids along the route of the longwall conveyor. The hull of the shearer, depending on the range of the height of the complex, can be equipped with cutting head drive units of varying different power. It should be noted that there is no need of building a haulage drive into the hull, which has a positive effect on the dimensions of the shearer. In addition to the drive unit, the hull contains a hydraulic system powered by the cutting head driving unit, as well as an automation, control and diagnostics system. The hydraulic system is necessary to change the position of the loaders and lift the entire shearer on its skids. The sizes of the individual elements were selected based on a preliminary calculation of power demand of the cutterhead, loading resistance and resistance to motion (Bołoz, 2018).

The mining machine working in the longwall system makes further cuts to the assumed depth (web) in the excavation of a certain height. The shearer works to thefull web along the entire length of the wall. Separation of the mining process from the loading process allows for achieving the assumed daily production. In the case of a change in the thickness of the deposit in the mining direction, it is possible to replace the cutting head with a larger or smaller one. Along with the change of the cutting head, it is also necessary to change the height of the shearer's foundation and the height of the loader. Therefore, taking into account the given range of mining heights, it was proposed to use a series of three longwall complexes with different wall height ranges. Such a solution will allow optimization of the system's parameters, in particular by diversifying the power of the drives used and limiting the working range of the roof support.

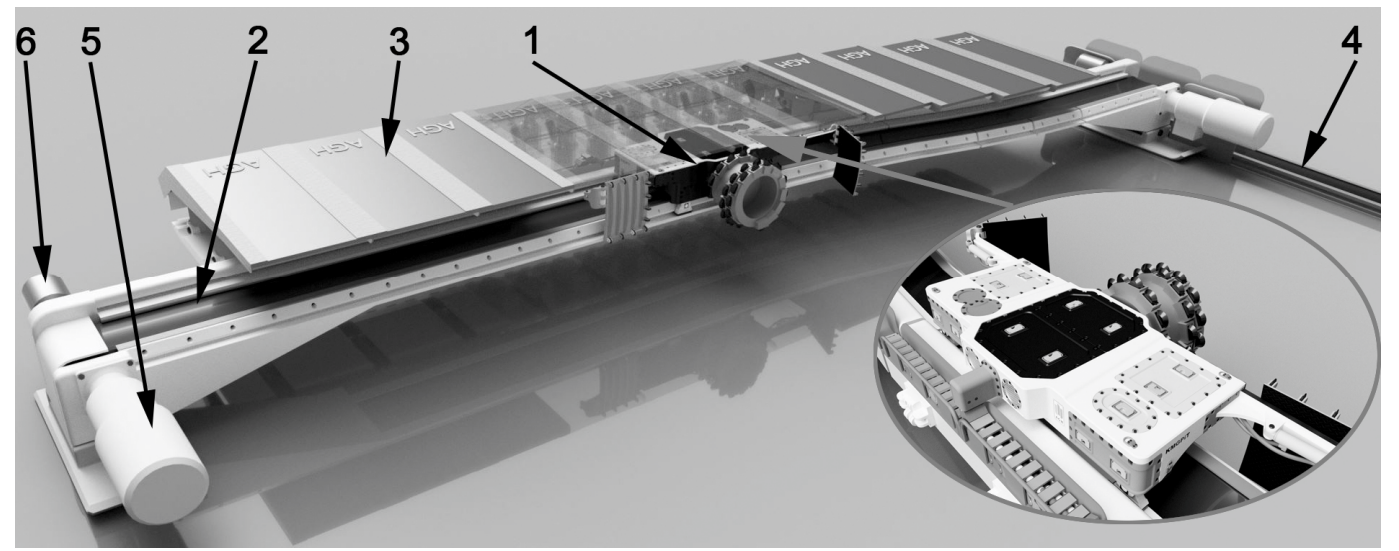

Fig. 2. Complex equipped with a longwall shearer

1. longwall shearer, 2. belt conveyor, 3. chock support, 4. low-face belt conveyor, 5. conveyor drive, 6 . drive of the shearer's chain haulage system.

\section{DAILY OUTPUT ANALYSIS}

Daily output, given in the form of the number of tons obtained from the wall during a day, represents the efficiency of the complex. A comprehensive analysis of efficiency was carried out and the value of possible daily output was obtained depending on the height of the wall, 
the cutting head's web, daily excavation time of the wall and fitting time along with time spent on organisational procedures. Sample diagrams of daily extraction as a function of individual parameters are presented in Fig. 3. The excavation system used is a very important factor affecting the daily output. The following parameter values were adopted for the calculations:

- $\gamma=2.65 \mathrm{Mg} / \mathrm{m}^{3}-$ density of the excavated rock,

- $t_{p o}=\{5 \mathrm{~min}, 10 \mathrm{~min}, 15 \mathrm{~min}\}$ - fitting and organisational time,

- $T=16 \mathrm{~h} / \mathrm{d}$ - daily wall excavation time $(12 \mathrm{~h} / \mathrm{d}$ in case of backfilling),

- $L=50 \mathrm{~m}$ - length of the survey wall $(50 \mathrm{~m} \div 180 \mathrm{~m}$ - range assumed for the efficiency analysis),

- $Z=\{0.6 \mathrm{~m}, 0.7 \mathrm{~m}, 0.8 \mathrm{~m}\}$ - cutting head's web,

- $H=\{1.0 \mathrm{~m}, 1.2 \mathrm{~m}, 1.4 \mathrm{~m}\} ;\{1.3 \mathrm{~m}, 1.5 \mathrm{~m}, 1.7 \mathrm{~m}\} ;\{1.6 \mathrm{~m}, 1.8 \mathrm{~m}, 2.0 \mathrm{~m}\}$ - height of the wall assumed for the efficiency analysis,

- strata management system: caving, backfilling.

Taking into account the requirement of full automation, the fitting time was assumed from the expected values ( 5 minutes) to the values resulting from the necessity to control and replace tools (10 minutes, 15 minutes).

In the case of a test heading with a length of only $50 \mathrm{~m}$, for the least advantageous combination of parameters and wall height of $1.0 \mathrm{~m}$, it is possible to extract $1174 \mathrm{Mg} / \mathrm{d}$ to 9 $393 \mathrm{Mg} / \mathrm{d}$ for a wall with a height of $2.0 \mathrm{~m}$. For a wall of standard length, exceeding $200 \mathrm{~m}$, the extraction rate will exceed the required $4000 \mathrm{Mg} / \mathrm{d}$.

It should be noted that the daily extraction values given refer to the mining machine itself. However, such a machine will work in a complex, where the other machines will also impact the final result. In order to achieve the assumed daily extraction rate, the speed of the mining machine must be greater than the value given. However, the permissible feed speed of the mining machine cannot exceed the speeds resulting from geometric and kinematic parameters of the armoured face conveyor, powered roof support and cutting heads (in the case of loading with cutterheads).
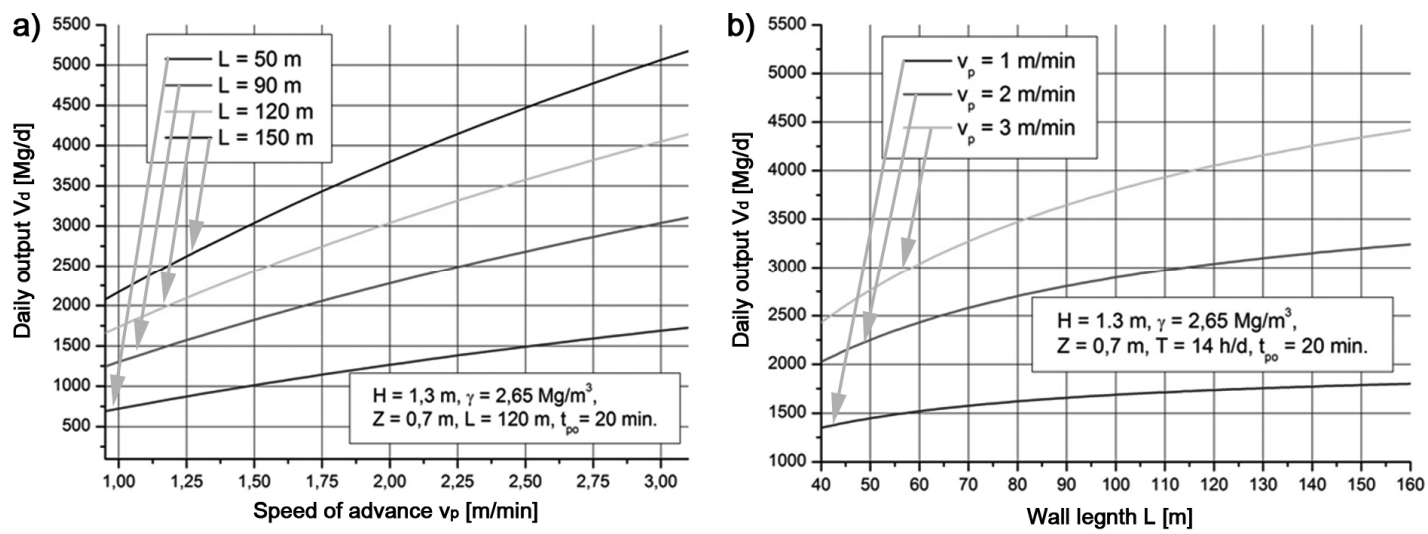

Fig. 3. Daily output of the wall $V_{d}$

a) as a function of the machine's feed speed $v_{p}$ depending on wall length b) as a function of wall length $L$, depending on the machine's feed speed $v_{p}$

Execution of a hydraulic backfill requires carrying out a number of processes aimed at filling the goaf without allowing the excavation to become flooded with water at the same time. Assuming that the time required for the execution of the backfill does not exceed 12 hours and that it is also carried out during the service shift, a daily wall working time of 12 hours was obtained. Therefore, daily mining will significantly decrease. Daily extraction, taking into account the assumptions made, will be reduced by $25 \%$.

The selection of the required parameters of the conveyor and roof support was made with the use of appropriate formulas (Krauze, 2000) and using good engineering practices. It was 
carried out separately for each wall height range. It should be noted that the choice of conveyor and support parameters is not affected by the daily wall excavation time, organizational times or wall length. The results obtained are summarized in Table 1.

Table 1

List of parameters of the face conveyor and roof support

\begin{tabular}{|c|c|c|c|c|c|}
\hline No. & $\begin{array}{c}\text { Face height } \\
{[\mathbf{~ m}]}\end{array}$ & $\begin{array}{c}\text { Feed speed } \\
{[\mathbf{m} / \mathbf{m i n}]}\end{array}$ & $\begin{array}{c}\text { Conveyor } \\
\text { efficiency }[\mathbf{M g} / \mathbf{h}]\end{array}$ & $\begin{array}{c}\text { Face conveyor belt } \\
\text { speed }[\mathbf{m} / \mathbf{s}]\end{array}$ & Section fitting time $\boldsymbol{t}_{\text {st }}[\mathbf{s}]$ \\
\hline 1. & $1.0 \div 1.4$ & & $\geq 900$ & $\geq 0.5$ & \multirow{2}{*}{$\leq 30$} \\
\cline { 1 - 1 } 2. & $1.3 \div 1.7$ & \multirow{2}{*}{$1 \div 3$} & $\geq 1000$ & $\geq 0.6$ & \\
\cline { 1 - 1 } 3. & $1.6 \div 2.0$ & & $\geq 1200$ & $\geq 0.8$ & \\
\cline { 1 - 1 } & & & &
\end{tabular}

A patented belt conveyor with a width of $850 \mathrm{~mm}$ and a height of $200 \mathrm{~mm}$ was selected for the complex. By changing the belt speed you can achieve the required efficiency for all height ranges. The support of the excavation consists of electrohydraulically controlled sections of the mechanized chock support with a spacing of $1.5 \mathrm{~m}$, an expansion height of $0.8 \mathrm{~m} \div 2.1 \mathrm{~m}$ and a fitting time not exceeding $30 \mathrm{~s}$. The support's expansion range should be limited and adapted to the specific size of the complex in accordance with the adopted type series.

\section{UNDERGROUND TESTS OF THE DISC CUTTING HEAD}

The first and the most important barrier in the case of mining thin ore deposits of hard and abrasive rocks is the cutting head that allows obtaining the planned daily production with its acceptable durability. As a result, an underground test of the cutting head designed in previous studies was planned and conducted (Fig. 4). A special station was developed and created and eighteen slices were made in the dolomites, sandstones and shales which occur in the excavation.
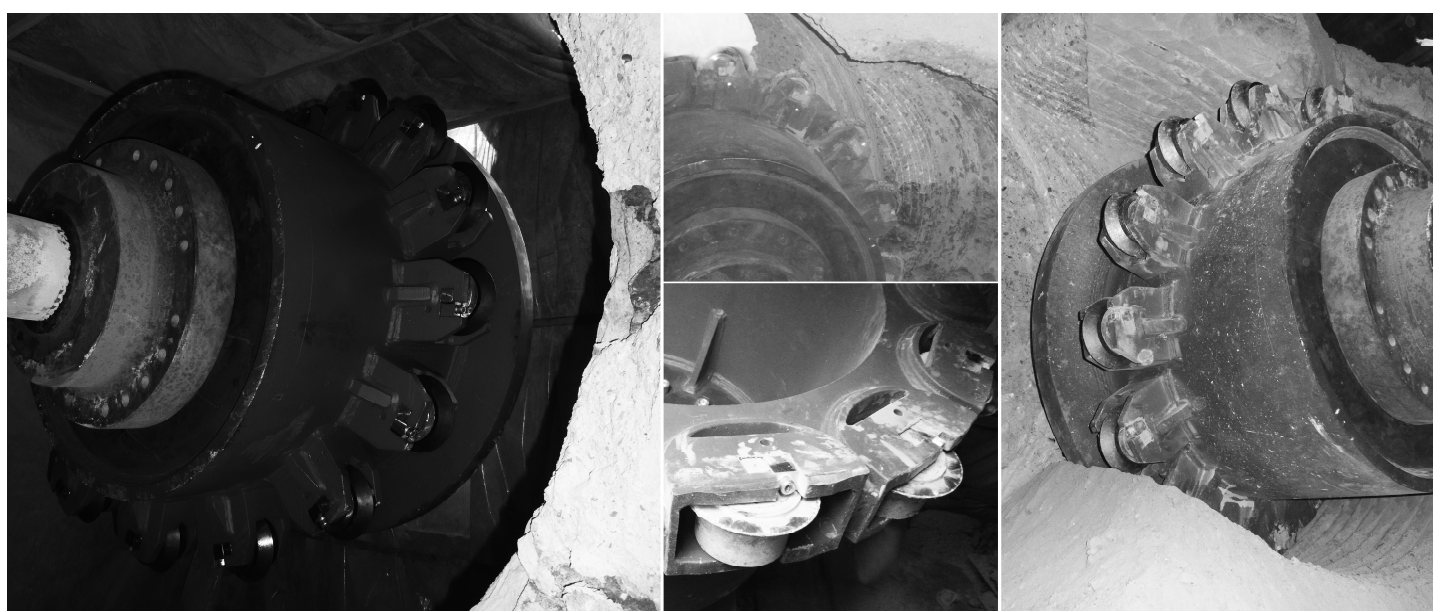

Fig. 4. Photos from disc cutting head tests

Research in real-life conditions has demonstrated the full susceptibility of rocks to mechanical excavation. The feed speed exceeded one meter per minute. Stable feed system, constant and high clamping force and high rotational speed of the cutting head ensure even and effective work. Due to the varied properties of the examined rocks, especially sandstone and dolomite, it is advantageous to develop the tool systems individually in order to obtain the lowest energy consumption and a favourable level of dust and muck grain size while protecting the cutting head's hull against abrasive wear. The weakest link in the cutting head under test is the durability of the disc bearing units. Bearings 
with the highest load capacity should be sought and the possibility of cooling the tools in a closed system considered.

\section{CONCLUSION}

The wall complex for the exploitation of thin seams equipped with a longwall shearer is designed for working in two-way mining. A characteristic feature of this technology is the lack of a sumping phase and exploitation to the full web at the entire length of the wall. If the height of the wall is changed, it is possible to change the diameter of the cutting head. Due to the seam's large thickness range, a series of complexes with different mining heights was proposed.

Based on the tests and conclusions from the implemented project, it was proposed to use a drum cutting head reinforced with disc cutters. The station tests of the cutting head allowed for the development of a solution designed for underground testing. The disc cutting head was tested in industrial conditions, where its suitability for mechanical excavation of this type of ore was proven.

The loading of excavated material is carried out by loaders, operating independently of the cutting head, thanks to which there is no contradiction between the parameters of the milling and loading processes. The chock powered roof support, due to a unique solution, provides constant support capacity, constant clearance area and high stability in comparison to chock and leg-shield supports working in the lower operating range.

The use of a face conveyor belt was proposed for guiding the mining machine and hauling away the output from the wall. This conveyor is a unique solution, which consists in carrying the carrier belt in gutters enabling the shearer to be guided. In addition, the special design of the gutters allows leaving excavated material on the floor, which could accumulate under the belt, inside the gutter.

The analysis of the possible daily output, taking into account the daily operation time and the length and height of the wall, according to the assumptions of the User, showed the possibility of achieving the planned daily extraction at the level of $4000 \mathrm{Mg} / \mathrm{d}$. However, a necessary condition is the lack of hydraulic backfill, which will significantly reduce daily output due to being time-consuming. In addition, daily output significantly depends on the amount of time spent on organisational procedures at the end of the wall and, first and foremost, on the feed speed of the shearer.

\section{REFERNCES}

Biały, W. (2014). Coal cutting force measurement system - (CCFM). In: 14th GeoConference on Science and Technologies In Geology, Exploration and Mining, SGEM2014, Albena, Bulgaria, Volume 3, pp. 91-98.

Biały, W. (2016). Determination of workloads in cutting head of longwall tumble heading machine. Management Systems in Production Engineering, 21(1), pp. 45-54.

Bołoz, Ł. (2013). Unique project of single-cutting head longwall shearer used for thin coal seams exploitation. Archives of Mining Sciences, 58(4), pp. 1057-1070.

Bołoz, Ł. (2018). Model Tests of Longwall Shearer with String Feed System. Archives of Mining Sciences, 63(1), pp. 61-74.

Bołoz, Ł. and Krauze, K. (2018). Ability to mill rocks in open-pit mining. In: 18th International Multidisciplinary Scientific Geoconference, Exploration and Mining, SGEM2018, Albena, Bulgaria, Voulme 2, pp. 41-48.

Fries, J., Onderkova, I. and Prochazka, M. (2016) Comparison of shearer sumping methods. In: 16th International Multidisciplinary Scientific Geoconference, Exploration and Mining, SGEM 2016, Albena, Bulgaria, Volume 2, pp. 141-148.

Gajewski, J., Podgórski, J., Jonak, J. and Szkudlarek, Z. (2008). Numerical simulation of brittle rock loosening during mining process. Computational Materials Science, 43(1), pp. 115-118.

Krauze, K. (2000). Urabianie skał kombajnami ścianowymi. Katowice: Wyd. Śląsk.

Krauze, K. and Bołoz, Ł. (2018). Disc unit dedicated to mine abrasive rocks and in particular copper ores. In: 18th International Multidisciplinary Scientific Geoconference, Exploration and Mining, SGEM2018, Albena, Bulgaria, Voulme 2. pp. 311-318. 
Krauze, K., Bołoz, Ł. and Wydro, T. (2015). Parametric factors for the tangential-rotary picks quality assessment. Archives of Mining Sciences, 60(1).

Krauze, K., Stopka, G. and Rączka, W. (2017). Design and test result of the new solution hydraulic roof support for low seams. In: 17th International Multidisciplinary Scientific Geoconference, Exploration and Mining, SGEM2017, Albena, Bulgaria, Voulme 17, pp. 189-196.

Mendyka, P., Kotwica, K. and Stopka, G. (2016). Innovative roadheader mining head with assymetrical disc to ols. In: 16th International Multidisciplinary Scientific Geoconference, Exploration and Mining, SGEM2016, Albena, Bulgaria, Volume 2, pp. 489-496.

Prostański, D. (2017). Models of zones protecting against coal dust explosion. Archives of Mining Sciences, 62(3), pp. 611-619.

Stopka, G., Gospodarczyk, P. and Kotwica, K. (2013). A new generation mining head with disc tool of complex trajectory. Archives of Mining Sciences, 58(4), pp. 985-1006.

Zasadzień, M. and Midor, K. 2015). Innovative application of quality management tools in a hard coal mine. In: 15th International Multidisciplinary Scientific GeoConference, Exploration and mining, SGEM 2015, Albena, Bulgaria, Volume 3, pp. 415-421. 